\title{
Ecology, Distribution, Harvest, and Conservation of the Amazonian Manatee Trichechus inunguis in Ecuador ${ }^{1}$
}

\author{
Robert M. Timm \\ Division of Mammals, Field Museum of Natural History, Chicago, Illinois 60605, U.S.A. \\ Luis Albuja V.
}

Departamento de Ciencias Biológicas, Escuela Politécnica Nacional, Apartado 2759, Quito, Ecuador

and

Barbara L. Clauson

Department of Mammals, Chicago Zoological Society, Brookfield Zoo, Brookfield, Illinois 60513, U.S.A.

\begin{abstract}
Recent summaries of the distribution of the Amazonian manatee Trichechus inunguis record specimens from much of the Central Amazon Basin in Brazil, eastern Perú, and extreme southeastern Colombia, but not Ecuador. During October and November of 1983 we searched for manatees in the Río Aguarico and Río Cuyabeno systems of Napo Province, eastern Ecuador. Herein we document the existence of Amazonian manatees in Ecuador, provide rough estimates of their current distribution, describe several aspects of their ecology in Ecuador, document use of manatees by indigenous peoples, and document the current commercial harvest of manatees for meat. Manatees were observed by us at several separate localities in the Amazonian lowlands of eastern Ecuador. Additionally, we report several observations by others as well as a published historical record previously overlooked. Our observations of manatees are from blackwater habitats in undisturbed, primary, lowland rainforest in water with a $\mathrm{pH}$ of 5.5 to 6.0 and temperature of 25.0 to $30.7^{\circ} \mathrm{C}$. In the upper Cuyabeno region, the Siona Indians, who have harvested manatees for generations, have a self-imposed ban on manatee hunting to protect the few remaining animals in their waters. Settlers, the military, and a commercial meat hunter continue to actively harvest Amazonian manatees in Ecuador and adjacent Perú. Much of the meat obtained is used by either the Ecuadorian or Peruvian military. We found manatees abundant at only one locality, Laguna Lagarto Cocha. However, this population is being actively hunted, and the meat sold to the local military outposts. We estimate that if the current level of harvest continues unabated, Amazonian manatees will be gone from Ecuador within 10-15 years.
\end{abstract}

\section{RESUMEN}

Recientes sumarios de la distribución de los manaties amazónicos Trichechus inunguis registran especímenes de la mayor parte de la cuenca amazónica en Brasil, el oriente de Perú, y el suroriente de Colombia, pero no de Ecuador. Durante octubre y noviembre de 1983 nosotros fuimos en busca de manaties en los sistemas de los ríos Aguarico y Cuyabeno de la Provincia del Napo, Ecuador oriental. Aquí documentamos la existencia de manaties amazónicos en Ecuador, proveemos estimaciones aproximadas de su actual distribución, describimos varios aspectos de su ecología en Ecuador, documentamos el uso de manatíes por gentes indigenas, y documentamos la cosecha comercial actual de manaties para carne. Manatíes feuron observados por nosotros en varias localidades separadas en las tierras bajas del Ecuador oriental. Adicionalmente, reportamos varias observaciones por otros, así como también registros históricos publicados que fueron previamente pasados por alto. Nuestras observaciones de manaties son de habitaciones en aguas negras en selva lluviosa primaria no alterada de tierras bajas, en aguas con un $\mathrm{pH}$ de 5.5 a 6.0 y temperatura de 25.0 a $30.7^{\circ} \mathrm{C}$. En la región del alto Cuyabeno, los indios de la tribu Siona, quienes han cosechado manaties por generaciones, se han impuesto así mismos prohibiciones en la caza de manatíes en Ecuador y tierras adyacentes de Perú. La mayoría de la carne obtenida es usada por los militares ya sea ecuatorianos o peruanos. Nosotros encontramos abundantes manaties sólo en una localidad, la Laguna Lagarto Cocha. Sin embargo, esta población está siendo activamente cazada, y la carne es vendida a los destacamentos militares del lugar. Estimamos que si el nivel actual de caza continúa al mismo ritmo los manatíes amazónicos habrán desaparecido del Ecuador en unos 10 a 15 años.

The Amazonian manatee Trichechus inunguis is one of the largest mammals on the South American continent; however, little is known of its ecology and distribution. Throughout the upper Amazon basin, T. inunguis is known as the "vaca marina," or sea cow. In Brazil it is known as the "peixi-boi," or fish ox. Recent summaries

${ }^{1}$ Received 26 July 1984, revision accepted 3 January 1985. of distribution cite specimens from much of the Central Amazon Basin in Brazil, eastern Perú, and extreme southeastern Colombia (Cabrera 1961, Bertram \& Bertram 1973, Husar 1977). Statements that the species occurs in the Orinoco drainage in Venezuela have been disproven by Mondolfi (1974), who showed that the manatees of the Orinoco basin are the West Indian species $T$. manatus. The paucity of data on Amazonian manatees is due in 
part to the difficulty in observing entirely aquatic mammals; inaccessibility of their habitat; and the shy, secretive nature of the animals. At the western edge of the range, Amazonian manatees have been reported in eastern Perú from the lower tributaries of the Amazon (Husar 1977, Thornback \& Jenkins 1982), and they are considered "nearer extinction than perhaps any other mammal of the Amazon region" (Grimwood 1968). On the basis of second-hand reports we suspected Amazonian manatees might also occur in eastern Ecuador (Figueroa \& Coello 1980, Albuja 1983), and during the fall of 1983 we searched for them in the Río Aguarico and Río Cuyabeno systems.

We have direct evidence that $T$. inunguis occurs in Amazonian Ecuador. We saw Amazonian manatees at several localities, in all Napo Province, and we examined skeletal remains from two individuals killed by local hunters. Additionally, we report several observations by others as well as an overlooked published historical record.

The objectives of this report are to document the existence of Amazonian manatees in Ecuador and to provide estimates of their current distribution, describe several aspects of their ecology, document use by indigenous peoples, and document the current commercial harvest of manatees.

A map of Ecuador and northern Perú (Fig. 1) shows the localities where we observed manatees and where those cited observations of others were made. Bracketed numbers, which follow, refer to localities plotted in Figure 1.

Localities of ObSeRVATIONS.-From 27 September to 1 October, we searched for manatees in the lagoon region of the upper Río Cuyabeno [1], concentrating our efforts around Laguna Grande $\left[00^{\circ} 00^{\prime}, 76^{\circ} 11^{\prime} \mathrm{W}\right.$, el. $\left.210 \mathrm{~m}\right]$. On 27 September we saw a manatee in the Río Cuyabeno, near Laguna Grande, and on 1 October two were seen at the confluence of Laguna Grande and the Río Cuyabeno. The Siona Indians, who served as our guides, informed us that there were few manatees in the lagoons at that time of year because they moved downstream into the larger rivers during the dry season. Surface-water temperatures of Laguna Grande ranged from 27.7 to $28.5^{\circ} \mathrm{C}$; $\mathrm{pH}$, taken in two areas, was 5.5. The water was dark tea color, with visibility of 1.0 to $1.5 \mathrm{~m}$. A cranium of an adult manatee, reportedly from the Cuyabeno region, is in the collections of the Departamento de Biología, Universidad Católica, Quito. The date of collection is unknown, but it has been at the university for several years (G. Orcés, pers. comm.).

On the evening of 27 October and morning of 28 October we searched for manatees at Laguna Zancudo Cocha $\left[00^{\circ} 33^{\prime} 40^{\prime \prime} \mathrm{S}, 75^{\circ} 29^{\prime} 30^{\prime \prime} \mathrm{W}\right.$, el. $200 \mathrm{~m}$ ], which is the largest blackwater lagoon in eastern Ecuador and drains into the Río Aguarico [2]. Surface-water temperature of the lagoon was $30.7^{\circ} \mathrm{C}, \mathrm{pH}$ was 6.0 , and the depth of the water was $2-3 \mathrm{~m}$ for most of the lagoon. The water was a dark tea color, with visibility to about $1.5 \mathrm{~m}$. The only manatee seen surfaced briefly approximately $4 \mathrm{~m}$ from our canoe, then disappeared. The sighting was in a bay that contained small, free-floating mats of the South American water hyacinth Eichbornia heterosperma [Pontederiaceae] (Fig. 2).

A settler living near Destacamento Militar Zancudo on the Río Aguarico informed us that in August 1983 he harpooned two manatees, one from laguna Zancudo Cocha and one from the channel draining that lagoon. The one from the lagoon was $2 \mathrm{~m}$ long. He sold the meat.

We saw several individuals on 1 November at Laguna Lagarto Cocha [3], about $25 \mathrm{~km}$ upstream from the mouth in Río Aguarico [ca $00^{\circ} 35^{\prime} \mathrm{S}, 75^{\circ} 15^{\prime} \mathrm{W}$, el. approximately $200 \mathrm{~m}$ ]. Surface-water temperature was $28.5^{\circ} \mathrm{C}, \mathrm{pH}$ was 5.5 . The water was a dark tea color with visibility of about $1 \mathrm{~m}$. We were given a manatee rib from this locality by a commercial meat hunter; it is deposited at the Escuela Politécnica Nacional.

Sr. Manuel Luna, Perito Forestal of the Ministerio de Agricultura y Ganadería, informed Albuja (1983) that in November of 1975 he observed four manatees in the Río Lagarto Cocha, a tributary of the Río Aguarico.

Of all our travels along the Río Aquarico and Napo systems, we found manatees abundant only in the Lagarto Cocha area. This may be the last lagoon system in the Napo basin where manatees are still abundant.

In October of 1981, while on a joint ichthyological expedition of the Escuela Politécnica Nacional and Field Museum of Natural History, Dr. Ramiro Barriga observed a manatee in the Río Yasuní [4] near its confluence with the Río Napo $\left[00^{\circ} 57^{\prime} 20^{\prime \prime} \mathrm{S}, 75^{\circ} 34^{\prime} 10^{\prime \prime} \mathrm{W}\right]$. The expedition was also told at the time by a local fisherman that manatees were occasionally hunted in the area, although they were not common. Surface-water temperature in 1981 was $27^{\circ} \mathrm{C}, \mathrm{pH}$ was 6.0 , and the water was a turbid, dark coffee color.

Señor M. Olalla informed Albuja (1983) that in 1983 he observed two manatees in the Río Añangu [5], a tributary of the Río Napo. On 10 October 1981, Donald J. Stewart recorded the surface-water temperature of the Añangu as $25.0^{\circ} \mathrm{C}, \mathrm{pH} 6.0$, and the water a dark tea color.

Philip Hershkovitz (pers. comm.) recalls that in 1936 he saw Amazonian manatees in the cochas north of the Río Napo near San Francisco [00 $\left.30^{\prime} \mathrm{S}, 76^{\circ} 22^{\prime} \mathrm{W}\right]$ [6]. $\mathrm{He}$ also informs us that in 1980 manatees seemed abundant in the blackwater Río Samiria in Depto. Loreto, Perú $\left[04^{\circ} 42^{\prime} \mathrm{S}, 74^{\circ} 13^{\prime} \mathrm{W}\right][7]$. He reports the animals grazed on grasses that grew along the edge of sand banks. These 


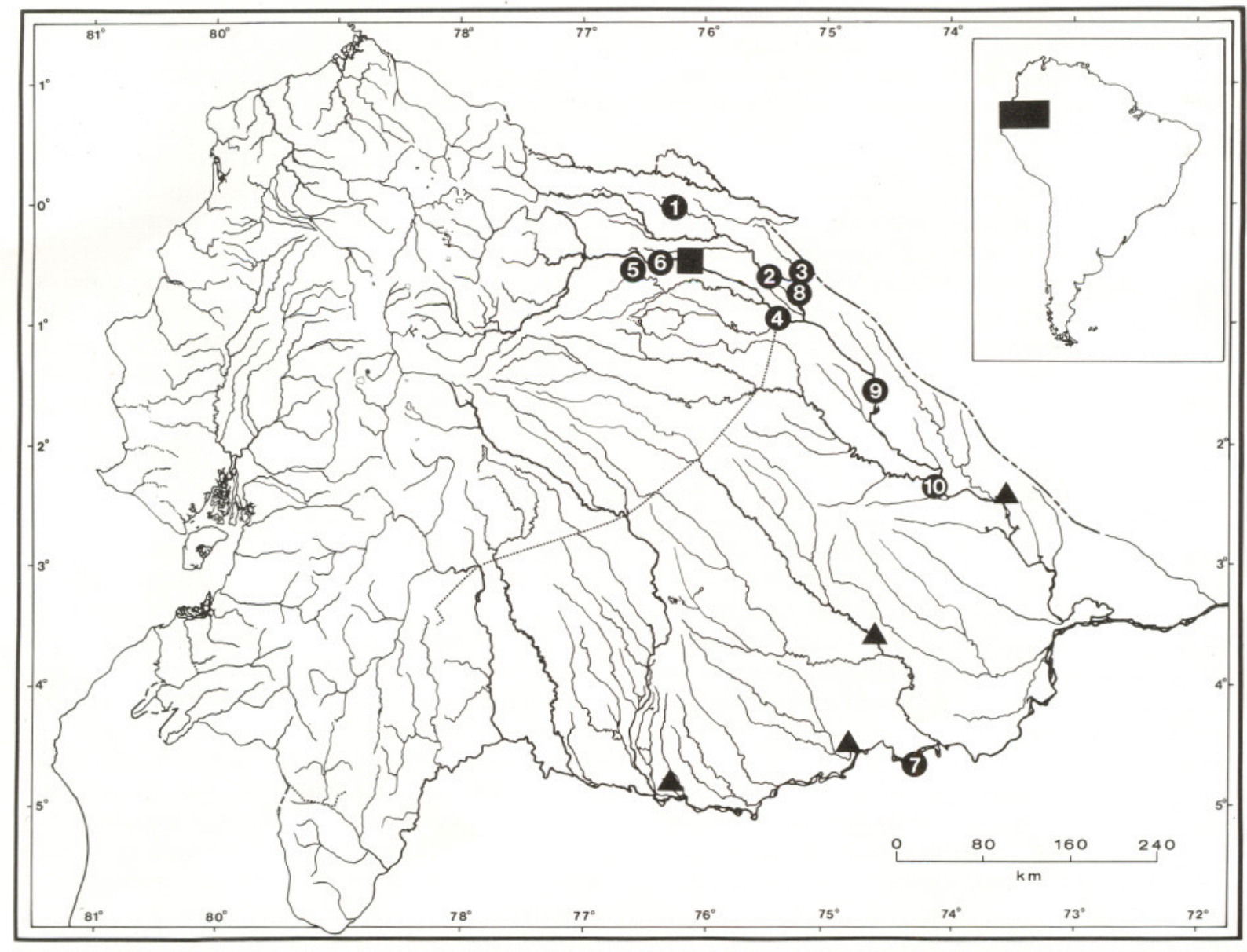

FIGURE 1. Drainage basin map of Ecuador and northern Perú with the major river drainages indicated. The circles represent localities mentioned in the text for which we are reporting sightings or specimens of the Amazonian manatee Trichechus inunguis. Numbers within the circles refer to specific locality descriptions presented in the text. The square represents the record of Amazonian manatees at Ciaja-coccia reported by C. Osculati (1854). The triangles represent documented records of Amazonian manatees taken from the recent literature (Cabrera 1961, Bertram \& Bertram 1973, Husar 1977).

grasses were bent down by the forelimbs to bring them within reach of the mouth so they could be cropped. The clipped grasses that sprang back into the upright position provided a sure sign of manatee feeding.

A commercial meat hunter, who specializes on manatees, told us of two lagoons where manatees were especially abundant, Laguna Imuya in Ecuador $\left[00^{\circ} 36^{\prime} \mathrm{S}\right.$, $75^{\circ} 15^{\prime} \mathrm{W}$ ] [8] and Loro Cocha in Perú, six hours downstream from Pantoja along the Río Napo [9].

The skull of an adult female $T$. inunguis collected at the mouth [10] of the Río Curaray, Perú $\left[02^{\circ} 22^{\prime} \mathrm{S}\right.$, $\left.74^{\circ} 05^{\prime} \mathrm{W}\right]$ by the Olalla brothers on 26 May 1926 is preserved in the collections of the American Museum of Natural History (AMNH 73594).

Lagunas Grande, Zancudo Cocha, and Lagarto Co- cha, as well as ríos Yasuní and Añangu, are all blackwater habitats in areas of undisturbed primary, lowland rainforest. The forests surrounding all known manatee localities in Ecuador are classified as Moist Forest in the Holdridge life zone system (Holdridge 1967) with the annual rainfall averaging from 2000 to $3000 \mathrm{~mm}$.

Historical RECORDS.-Although several recent reviews on Amazonian manatees (e.g., Bertram \& Bertram 1973, Husar 1977, Whitehead 1977), do not include Ecuador within the known distribution of $T$. inunguis, we are not the first to record manatees from this country. In 1850 , Caetano Osculati, an Italian explorer-naturalist, reported on his travels in central South America in the late 1840's. He started in Quito, progressing eastward across Ama- 


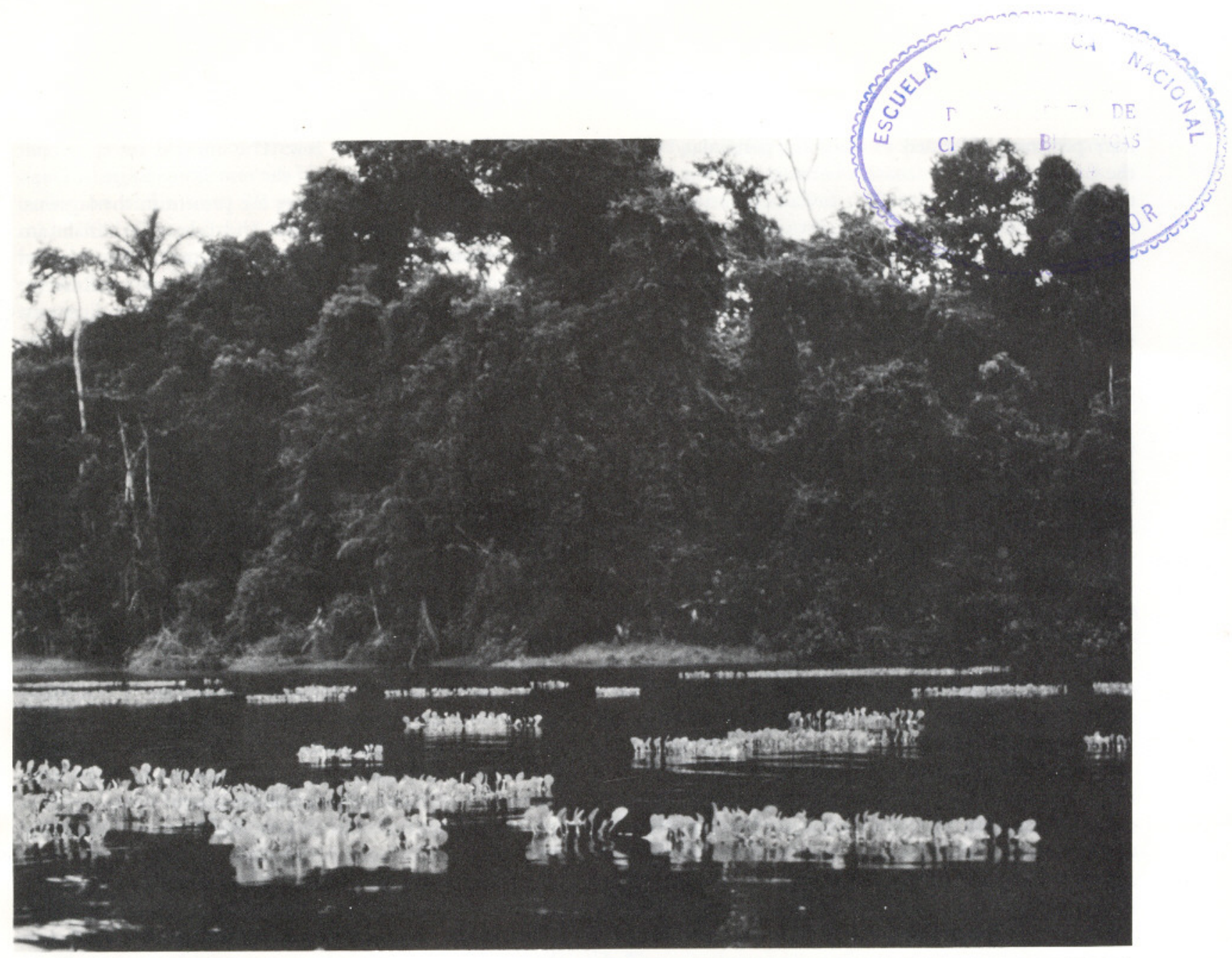

FIGURE 2. A bay in Laguna Zancudo Cocha, the largest blackwater lagoon in eastern Ecuador, with free-floating mats of the water hyacinth Eichbornia beterosperma. A single Amazonian manatee was observed by us here. This is typical of habitats where manatees occur in Ecuador. Photograph by Barbara L. Clauson.

zonian Ecuador, Perú, and Brazil. He records a local fisherman capturing a manatee in eastern Ecuador, stating "Erasi Arrebalo recato al lago di Ciaja-coccia alla pesca dei lamantini (Manatus americanus. Cuvier), che ivi incominciansi a trovare rimontando il fiume delle Amazzoni, dove sono comunissimi. Avendo spedito un indiano in una canoa a renderlo avvertito del mio arrivo, egli non tardò a ritornare, riportando una ricca preda di scimmie ed un piccolo lamantino" (Osculati [1850] 1854:15) [= Erasi Arrebalo had gone to lagoon Ciaja-coccia to fish for manatee ... which are to be found there coming upstream from the Amazon, where they are common. Having dispatched an indian in a canoe to let him know of my arrival, he wasn't long in returning to report a rich catch of monkeys and a small manatee]. Although Ciajacoccia is not identified as such on modern maps, judging from Osculati's map, it would be a lagoon north of the Río Napo near San Roque or Pañacocha, Napo Province [ca $00^{\circ} 26^{\prime} \mathrm{S}, 76^{\circ} 4-11^{\prime} \mathrm{W}$ ]. Osculati's record of manatees along the Río Napo of Ecuador has been overlooked in all subsequent works on this species.

Diet.-Amazonian manatees have been reported to feed on a variety of aquatic macrophytes including aroids, grasses, bladderworts, hornworts, water lilies, and water hyacinths (Husar 1977; Best 1981, 1983; Montgomery et al. 1981). A thorough review of foods and feeding habits of all the Sirenia was provided by Best (1981). As we have not watched manatees feeding, we have no direct information on foods eaten by Amazonian manatees in Ecuador. However, we do have information from local hunters familiar with the manatee on which plants were favored food items.

At Zancudo Cocha we saw a single manatee in a small bay containing large mats of the floating water hyacinth Eichbornia beterosperma (Fig. 2). The local mil- 
itary personnel informed us that this particular bay was the best place to see manatees because they fed there on the hyacinth; it was also their favorite hunting area for manatee. This bay had the highest concentration of hyacinth that we noted in the lagoon.

At Lagarto Cocha a commercial meat hunter who specialized in manatees, pointed out several species of aquatic plants that they ate. His information was based on many years of hunting manatees and in keeping a young, wild-caught animal in captivity for several months. They include: water hyacinths Eichbornia crassipes, Eichbornia diversifolia, and Eichbornia heterosperma; aquatic grass Hymenachne donacifolia [Gramineae]; bladderwort Utricularia foliosa [Lentibulariaceae]; and Ludwigia adscendens [Onagraceae]. Reference specimens of these are on deposit in the herbarium at the Field Museum of Natural History, Chicago. He also mentioned another grass gramalote (Pennisetum) [Gramineae] that the manatees feed on, but we were unable to obtain reference material. At Laguna Canangüeno our Siona Indian guide pointed out two species of aquatic plants Eichbornia diversifolia and Najas arguta [Najadaceae] as being important manatee food.

Reproduction.-In the Lagarto Cocha area, the professional hunter said that the young are born in January. On 15 October 1983 he captured an adult female with a large fetus. Of all the females harpooned over the years, he has never found more than a single young with each. Pregnant females are found in the fall. In 1983 he took a pregnant female in mid-October. The newborn are dark grey to blackish in color, similar to the adults and may be $60-80 \mathrm{~cm}$ long. In the Cuyabeno region, we were told by the Siona that the young were born in June. In December several years earlier, our Siona guide in the Cuyabeno harpooned an adult female accompanied by a calf. In eastern Ecuador, the time period from May through August corresponds to the rainy season when the water levels of the lagoons and rivers would be highest.

Harvest.-The Siona Indians of Amazonian Ecuador have harvested manatees for generations. Manatee hunting is a skill passed from father to son. Historically, the habitat available for manatees within their lands has been extensive, and the population of Siona sparse. Hence, the few animals they harvested each year probably had little longterm effect upon the manatee population. Even today the number of Siona totals only some 40 individuals (Figueroa \& Coello 1980). However, with oil exploration in the area and the construction of new roads bringing in settlers and the military, the demand for animal protein has increased. Increased hunting pressure has caused the population of manatees to decline severely. The Siona have not hunted manatees for the past six years, inform- ing us that there are too few. The impetus for their ban on hunting is conservation of the remaining animals. During the rainy season, manatees are present in the lagoons which the Siona regularly hunt and fish; they remain an easily obtainable source of animal protein. The lagoon region of the upper Cuyabeno is now a reserve, Reserva de Producción Faunística Cuyabeno. Only the indigenous peoples, the Siona, are allowed to hunt and fish there, although poaching does occur.

The commercial meat hunter mentioned above lives on the shore of Laguna Redondo Cocha near Río Lagarto Cocha and near the Ecuador-Perú border. He is a native Peruvian whose hunting operations include the rivers and lagoons on both sides of the border. His income is derived almost entirely from supplying meat to local Ecuadorian and Peruvian military bases. Currently, the meat is obtained primarily from two native species-Amazonian manatees and paiche. The paiche (Arapaima gigas, Osteoglossidae) is the largest freshwater fish in South America, reaching a length of over $3 \mathrm{~m}$ and a weight of 150 $\mathrm{kg}$ (Goulding 1981). He informed us that he has lived in this area for the past eight months and during that time he has taken seven to ten manatees. Prior to this he lived and hunted near Pantoja, Perú $\left[00^{\circ} 57^{\prime} \mathrm{S}, 75^{\circ} 10^{\prime} \mathrm{W}\right]$, where he had hunted manatees for several years.

In the Lagarto Cocha area, he finds manatees virtually everywhere in the lagoons, especially when the water level goes down in the dry season (November-March). They can be seen at almost any hour of the day, but hunting is best in the early morning or at dusk, especially if it is cloudy. While hunting he sees manatees coming up to breathe roughly every 40 minutes. Of all the manatees he has taken, about half have been females. The largest manatee he has taken in the Lagarto Cocha area weighed $480 \mathrm{~kg}$. The bigger lagoons, especially those farther from the main rivers, have the most manatees.

He hunts manatees with one or two assistants. They approach the selected animal, whether it be a manatee or paiche, very quietly in his dugout canoe. He throws the 3 -m-long harpoon from a distance of some $6 \mathrm{~m}$. The steel tip or "anzuelo" is barbed and embeds deeply into the prey. The anzuelos are purchased in either Lima, Perú, or in Brazil.

Conservation of manatees in Ecuador.-The four extant species of Sirenia, the dugong Dugong dugon, the West Indian manatee Trichechus manatus, the West African manatee $T$. senegalensis, and the Amazonian manatee, have been heavily exploited by man throughout history. Today the geographic ranges and population densities of the four species have been so reduced that all are included in the International Union for Conservation of Nature and Natural Resources' (IUCN) Red Data Book (Thornback \& Jenkins 1982) as Vulnerable. The fifth and 
largest species of Recent Sirenia, Steller's sea cow Hydrodamalis gigas of the western Bering Sea, was hunted to extinction within some 30 years after its discovery in the mid-1700's (Domning 1972). Amazonian manatees have been harvested for perhaps as long as man has inhabited the Amazon Basin. Manatees have been a preferred meat source, in part because they are large, slow-moving animals that provide a great deal of meat. Also, manatees are perhaps the easiest and safest large animals for a hunter to capture. Additionally, manatee meat is said to have a property that renders it slow to decay, an important factor in the tropics where salt is scarce. Excellent historical reviews of manatee distribution and hunting in South America were provided by Baughman (1946), Domning (1981, 1982), and Whitehead (1977, 1978).

Prior to contact with western man, indigenous tribes utilized "harpoons fitted with shell points" to hunt manatees (Smith 1981), and early explorers found manatee meat routinely available in local villages throughout the Amazon basin. In addition to providing a source of meat and oil, the manatee furnished thick hides which were used for war shields and dense bones used for utensils (Nimuendajú 1952). Yet even though heavily used by the indigenous peoples, early explorers recorded manatees as abundant. This abundance in spite of exploitation led Smith (1981) to suggest that there were "cultural checks to over-exploitation" by indigenous peoples. We found the Siona to have a strong conservation ethic, which included a self-imposed ban on manatee hunting in recent years because of low manatee populations.

Siona game harvesting would best be described as subsistence hunting. The Siona obtain a wide array of animals for food; however, the majority of their animal protein is obtained from fish which are either speared or caught with hook and line. Because of the nature of their hunting techniques, there is little to no negative impact upon populations of game species.

The commercial meat hunter told us that during his years as a meat hunter in northern Perú and eastern Ecuador, he has killed some 100 manatees; we do not believe he was exaggerating. Currently, he is the only person in the area hunting manatee and paiche on a commercial basis. He informed us that he was limited not by the abundance of game or his ability to obtain it, but by the price and availability of salt to preserve the meat. Much of Ecuador's salt producing capacity was greatly reduced by the recent El Niño anomaly (1982-83), creating shortages of salt and higher salt prices. He told us that if salt were available, he would hunt manatees every day with the objective of obtaining one adult or two juveniles for each day's effort.

The plight of the manatee has worsened recently; in Perú, Grimwood (1968:418) stated that Trichechus inunguis was "now so rare that only by the prohibition of all hunting can the species be saved." Heightened political tension between Ecuador and Perú has brought a markedly increased military presence to this remote frontier region near their international boundary, thus creating a ready market with the military for as much meat as can be supplied. Additionally, increased oil exploration and drilling in Amazonian Ecuador is leading to increased water pollution, which may have a negative impact on manatee populations.

During the dry season, manatees may be especially vulnerable to hunters. In the lagoon regions they occupy, such as the upper Cuyabeno, water levels decrease during the dry season to the point where only a single channel remains. The seasonal movements of manatees into the large shallow lagoons during the rainy season and into the larger rivers during the dry season creates a predictable pattern that may increase their vulnerability. This need to migrate may be one reason lagoons without appropriately deep connections to large rivers do not have manatees.

All recent records of Amazonian manatees from Ecuador are from areas of blackwater lagoons and rivers with a $\mathrm{pH}$ of 5.5 to 6.0 and surface-water temperature of 25.0 to $30.7^{\circ} \mathrm{C}$. Large blackwater lagoons with deep connections to big rivers and abundant macrophytes appear to be key habitat requirements for Amazonian manatees. Elsewhere in eastern Ecuador, blackwater lagoons, similar to those where we observed manatees, exist in the lower Pastaza and Tigre river systems. It seems likely that Amazonian manatees will also occupy those drainages.

The apparent absence of manatees along large, whitewater rivers may reflect the absence of appropriate macrophyte foods. Strong currents, eroding banks, and waterlevel instability may also be a factor. Deforestation and the associated increased erosion could have a severe impact upon manatees through degradation of water quality and subsequent reduction of food plants.

We noted a high correlation between manatees and emergent macrophytic vegetation. Thus, it should be feasible to locate and identify potential manatee habitat via aerial surveys. Sites with the appropriate habitat available can be identified for follow-up ground surveys and protection.

If manatees are to survive in Ecuador, they must receive complete protection immediately. The current level of commercial and subsistence hunting coupled with the low reproductive rate of manatees makes their present status precarious at best. Protection of the Lagarto Cocha populations is especially difficult because of the remoteness of the region, the international nature of the waterways, and the current demand for animal protein by the military personnel of both countries. An international agreement between Ecuador and Perú giving manatees complete protection may be needed. Manatees in the upper Cuyabeno 
region are protected as part of the Reserva de Producción Faunística Cuyabeno; however, poaching does occur and will increase as settlements encroach upon the park. Also, the small population of manatees living there is especially threatened during the dry season as they move downstream into the major rivers outside of the park's boundaries. The upper Yasuni and Añangu are both included within Parque Nacional Yasuni; thus, the manatees there are protected by law. However, there is a lack of personnel to enforce wildlife laws in this remote region. Effective conservation of manatees requires complete protection of all existing populations, and additional information on their current abundance, migrations, and habitat requirements. We estimate that if the current level of harvest continues unabated, Amazonian manatees will be gone from Ecuadorian waters within 10-15 years.

\section{ACKNOWLEDGMENTS}

We are grateful to Donald J. Stewart and Myriam Ibarra for logistic support while in Ecuador, providing the water chemistry data, and for critically reading the manuscript and providing valuable suggestions. Ramiro Barriga, Angelitos Garrett, and Gustavo Orcés provided logistic assistance in Ecuador. Daryl P. Domning, Alfred L. Gardner, and Philip Hershkovitz provided valuable reviews on the manuscript, and Hershkovitz the historical records. We thank the Comandancia General del Ejército Ecuatoriano, the Corporación Estatal Petrolera Ecuatoriana, and the Ministerio de Agricultura y Ganadería for assistance and logistic support. Penny Matekaitis and Timothy Plowman of the Field Museum identified the voucher specimens of aquatic plants for us. This project was funded in part by a grant from the National Science Foundation, INT-8303194, with supplemental support from the Escuela Politécnica Nacional, Field Museum of Natural History, and the Chicago Zoological Society.

\section{LITERATURE CITED}

Albuja V., L. 1983. Mamíferos ecuatorianos considerados raros o en peligro de extinción. Ministerio de Agricultura y Ganadería, Departamento de Administración de Areas Naturales y Vida Silvestre. Quito, Ecuador.

Baughman, J. L. 1946. Some early notices on American manatees and the mode of their capture. J. Mamm. 27: $234-239$.

Bertram, G. C. L., and C. K. R. Bertram. 1973. The modern Sirenia: their distribution and status. Biol. J. Linnean Soc. 5: $297-338$.

Best, R. C. 1981. Foods and feeding habits of wild and captive Sirenia. Mamm. Rev. 11: 3-29.

- 1983. Apparent dry-season fasting in Amazonian manatees (Mammalia: Sirenia). Biotropica 15: 61-64.

Cabrera, A. 1960 [1961]. Catálogo de los mamíferos de América del Sur. Rev. Mus. Argentino Cienc. Nat. "Bernardino Rivadavia" 4(2): 309-732.

Domning, D. P. 1972. Steller's sea cow and the origin of North Pacific aboriginal whaling. Syesis 5: $187-189$.

- 1981. Distribution and status of manatees Trichechus spp. near the mouth of the Amazon River, Brazil. Biol. Conserv. 19: 85-97.

- 1982. Commercial exploitation of manatees Trichechus in Brazil c. 1785-1973. Biol. Conserv. 22: $101-126$.

Figueroa S., S., AND F. Coello H. 1980. Proyecto delimitación de territorios nativos Siona-Secoya-Cofán y Huaorani parametro biológico. Ministerio de Agricultura y Ganadería, Dirección General de Desarrollo Forestal, Departamento de Administración de Areas Naturales y Vida Silvestre. Guayaquil No. 17-40, Quito, Ecuador. 35 pp. + appendix and maps,

Goulding, M. 1981. Man and fisheries on an Amazon frontier. Developments in Hydrobiology 4. Dr. W. Junk Publishers, London. 137 pp.

Grimwood, I. 1968. Endangered mammals in Peru. Oryx 9: 411-421.

Holdridge, L. R. 1967. Life zone ecology. Tropical Science Center, San José, Costa Rica. 206 pp.

Husar, S. L. 1977. Trichechus inunguis. Mamm. Species 72: 1-4.

Mondolfi, E. 1974. Taxonomy, distribution and status of the manatee in Venezuela. Mem. Soc. Cienc. Nat. La Salle 34(97): 5-23.

Montgomery, G. G., R. C. Best, and M. Yamakoshi. 1981. A radio-tracking study of the Amazonian manatee Trichechus inunguis (Mammalia: Sirenia). Biotropica 13: 81-85.

Nimuendajú, C. 1952. The Tukuna. Univ. California Publ. Amer. Archaeol. Ethnol. 45: ix + 1-210.

Osculatı, C. [1850,1st edition, not seen $\} 1854$. Esplorazione delle regioni equatoriali: Lungo il Napo ed il fiume delle ammazzoni frammento di un viaggio fatto nelle due americhe negli anni 1846-47-48. Fratelli Centenari e Comp., Milan, 344 pp. + 15 figs. and map, 2nd edition.

S

Thornback, J., AND M. Jenkins. 1982. The IUCN mammal red data book. International Union for Conservation of Nature and Natural Resources, Gland, Switzerland.

WhiteheAd, P. J. P. 1977. The former southern distribution of New World manatees (Trichechus spp.). Biol. J. Linnean Soc. 9: $165-189$.

. 1978. Registros antigos da prescença do peixe-boi do caribe (Trichechus manatus) no Brasil. Acta Amazonica 8: 497506. 